\title{
Yhdyskuntasuunnittelun sosiologisia tutkimustehtäviä
}

\author{
Valtiot. tri PAAVO PIEPPONEN \\ Väestöpoliittinen Tutkimuslaitos
}

\section{SUUNNITTELU JA ARVOT}

Kaikessa sosiaalisessa suunnittelussa tulisi hallita kaksi elementtiä. Ensimmäinen näistä on tavoitteiden tunteminen ja toinen niiden keinojen määritteleminen, joilla tavoitteisiin päästään. On osoitettu esimerkiksi, että keisarinajan kaupunkisuunnittelussa Helsingissä heijastui sen ajan sosiaalinen organisaatio ja arvot. Kirkot ja hallituspalatsit sijoitettiin kaupungin keskustaan ja näiden valtaa symbolisoitiin vielä arkkitehtonisin tehokeinoin. Säätyyhteiskunnan kerrostuneisuutta ylläpidettiin segregation, erottelun avulla (Allardt $\longrightarrow$ Littunen 1961, 279).

Nykypäivän yhdyskuntasuunnittelu perustuu nyky-yhteiskunnan tavoitteisiin eli arvoihin ja käyttää keinoja, joilla nämä tavoitteet saavutetaan. Mutta mitkä ovat nykyaikaisen yhteiskunnan keskeisimmät tavoitteet, jotka yhdyskuntasuunnittelussa tulisi ottaa huomioon? Vaikka jotkut arvot vaihtelevat ryhmästä toiseen, on kuitenkin arvoja, jotka ovat kaikkien hyväksymiä. Sosiologinen tutkimus voi kuvailla ja analysoida yhteisiä ja eri ryhmien arvoja, niissä tapahtuvia muutoksia sekä sitä, miten arvoja voidaan muuttaa. Yhdyskuntasuunnittelussa jos missä joudutaan tekemisiin eri arvojen ja eri ryhmien keskenään ristiriitaisten arvojen kanssa. Ovatko esimerkiksi arkkitehtien arvot ensi sijassa esteettisiä, kauniisiin rakennustaiteellisiin saavutuksiin pyrkiviä? Miten maanomistajien arvot vaikuttavat suunnitteluun? Mitä perheellä, asunnontarvitsijalla on mielessään, kun se valitsee uutta asuntoa? Tässä esitetään vain muuta- mia kysymyksiä, joihin joku voi vastata suoralta kädeltä, mutta jotka kenties kuitenkin vaatisivat tarkempaa erittelyä.

\section{YHTEISKUNTA JA YHDYSKUNTA- SUUNNITTELU}

Yhdyskuntasuunnittelija on samalla yhteiskuntasuunnittelija. Sen tähden hänen olisi tunnettava yhteiskunnassa vallitsevat sosiaaliset prosessit. Näistä hänen työhönsä likeisimmin liittyvät elinkeinoelämän rakennemuutos ja yhteiskunnan kaupungistuminen.

\section{Yhdyskuntien toiminta}

Elinkeinoelämän rakennemuutoksen joutuu suunnittelija ottamaan huomioon, kun hän selvittää itselleen, mitkä ovat yhdyskunnan taloudelliset tehtävät. Suunnittelija joutuu pohtimaan mm. kysymystä, onko tarkoituksenmukaista rakentaa yhdyskunta, joka on toiminnallisesti erikoistunut vai sellainen, jossa elinkeinoelämän eri sektorit ovat edustettuina. Sosiologi voi jälleen auttaa suunnittelijaa tutkimalla yhdyskuntien toiminnallista erikoistumista, erikoistumisen edellytyksiä ja seurauksia. Edelleen sosiologi voi tutkia erikoistuneiden ja erikoistumattomien yhdyskuntien väestön viihtyvyyttä.

\section{Yhdyskuntien koko}

Väestön kasautumisen voimistuessa joutuu suunnittelija pohtimaan myös kysymystä yhdyskunnan koosta. Ei liene näet suinkaan samantekevää, asuuko miljoona ihmistä yhdessä miljoonakaupungissa vai viidessä 200000 asukkaan kaupungissa. 
Tutkimukset ovat osoittaneet, että koko yhteiskunnan puitteissa kaupunkien koon ja järjestysluvun välillä vallitsee tietty laki. Tämä ns. Zipfin laki sanallisesti ilmaistuna merkitsee, että kunkin kaupungin väkiluvun ja järjestyssijan tulo on sama kuin suurimman kaupungin väkiluku. Tämä lainmukaisuus, joka täysin vastaa todellisuutta ilmeisesti vain hyvin suurilla talousalueilla, valaisee eräitä yhdyskuntapoliittisia heikkouksiamme. Meillähän toiseksi suurimman kaupungin väkiluku kerrottuna 2:1la ei vastaa suurimman kaupungin väkilukua. Kiiskinen (1954, 103-105) on analysoinut maamme väestökeskusten suuruussuhteita vv. $1750-1950$. Hän totesi, että käyrien muodossa oli porrastumista suurimpien kaupunkien kohdalla ja että hallinnollisten jakoperusteiden mukaan saadaan varsin puutteellinen kuva väestön keskittymisilmiöstä ja sen laajuudesta. Suurimpien kaupunkien väkilukujen suhteet siten eivät ole soikeat».

Kysymys kaupungin ihannekoosta kiehtoo suunnittelijaa. Se on kiehtonut muitakin, sillä jo Platon aikanaan esitti kaupungin optimikooksi 5040 henkeä (Heinilä 1962, 28-29). Tätä hän perusteli sillä, että sen kokoinen väestö yhtä aikaa voi kuulla puhujan äänen ja voi siten osallistua poliittiseen elämään. On tietysti mahdoton määritellä kaupungin optimikokoa, joka olisi ihanteellinen kaikkien arvojen mukaan, sillä arvioinnissa joudutaan ottamaan huomioon jälleen erilaiset arvot. Tätä tulisi kuitenkin tutkia. Tässä tutkimuksessa olisi otettava huomioon monia sellaisia tekijöitä, joita pidetään arvokkaina ja tarkasteltava sitten, missä kaupunkikoossa se esiintyy edullisimmassa suhteessa. Duncan on luetteloinut eräitä perusteita, joiden mukaan optimikoko olisi arvioitavissa (Heinilä 1962, 29).

Terveydelliset olot, turvallisuus, hallinnollinen tehokkuus ja monet muut tekijät olisi tutkittava kaupungin koon vaihdellessa. Vaikkei tällainen tutkimus antaisikaan ehdotonta vastausta siihen, mikä on suomalaisen kaupungin ihannekoko, se osoittaisi kuitenkin, mikä on tiettyjen ilmiöiden väestöperusta - sekä positiivisina että negatiivisina pidettyjen ilmiöiden.

\section{Yhdyskuntien sijainti}

Sekä elinkeinoelämän rakennemuutokset että kaupungistuminen olisi otettava huomioon, kun suunnittelija ajattelee uusien yhdyskuntien sijaintia. Mitään ehdottomia ohjenuoria ei ole olemassa yhdyskunnan sijainnin määräämisessä. On kyllä kehitetty keskusten sijaintia koskevia teorioita (esim. Christaller), mutta ne soveltuvat huonosti meidän oloihimme ja luontoomme. Sen sijaan voitaisiin sijaintia määrättäessä lähteä liikkeelle seuraavista kysymyksistä. Onko uusi yhdyskunta, esim. kaupunki rakennettava sinne a) missä raaka-aineet ovat, b) missä väestö on vai c) minne muuttovirrat suuntautuvat? Tutkimalla nykyisten kaupunkien sijaintia niiden taloudellisten tehtävien ja väestön uudelleen jakautumisen kannalta voitaisiin saada tietoja, jotka ehkä antavat viitteitä mitä vaikutuksia uusilla kaupungeilla on yhteiskuntaan.

Jos taas lähdetään siitä, että yhdyskunnan sijainti on määrätty - kuten se useimmiten on - olisi tutkittava, mitä vaikutuksia sillä on sen välittömään vaikutusalueeseen. Toiminnan ja väestön alueellisen jakautumisen kannalta voidaan tätä arvioida tutkimalla nopeasti kasvaneiden yhdyskuntien olosuhteita.

\section{YHDYSKUNTA JA SEN SUUNNITTELU}

Siirryttäessä valtakunnalliselta tasolta paikkakunnalliselle tasolle ts. yksityiseen yhdyskuntaan kohtaa suunnittelija jälleen joukon ongelmia. Ne voidaan ryhmitellä seuraaviksi: yhdyskunnan fyysillinen perusta, sosiaalinen perusta ja biologinen perusta. Nämä kaikki ovat vuorovaikutuksessa keskenään ja yhteydessä sosiaalisiin arvoihin ja sosiaalisiin prosesseihin.

Fyysillinen perusta. Niinkin vähäpätöiseltä tuntuvalla seikalla kuin yhdyskunnan muoto saattaa olla kauaskantoisia seurauksia. Ajateltakoon vain Helsinkiä kapealla niemellä. Vertaamalla fyysillisiltä piirteiltään eri muotoisia keskuksia voi tutkija osoittaa ehkä eräitä säännönmukaisuuksia, jotka suunnittelijan olisi otettava huomioon työssään. 
Maankäytön suunnittelu on kaikkein vaikeimpia tehtäviä yhdyskuntasuunnittelussa. Siinä joudutaan ottamaan huomioon erilaisia arvoja, siinä on muistettava vallitsevat sosiaaliset prosessit sekä myös yhdyskunnan fyysillinen, sosiaalinen ja biologinen perusta. Mielestäni kiireellisin tutkimustehtävä fyysillistä perustaa määriteltäessä olisi tutkia eri kaupunkien maankäyttöä, syitä, jotka ovat johtaneet tietynlaiseen käyttöön ja erilaisen maankäytön seurauksia väestölle ja sosiaalisille laitoksille.

Sosiaalinen perusta. Yhdyskunta on ihmisen luoma ympäristö. Se ei ole ainoastaan fyysillinen, vaan myös sosiaalinen ympäristö. Kun ajatellaan yhdyskuntaa sosiaalisena ympäristönä, on ensiksi muistettava sen sosiaalinen rakenne ja väestönmuutokset. Väestön sosiaalisessa rakenteessa suunnittelijaa tulisi kiinnostaa ennenkaikkea demografinen rakenne ja stratifikaatio, kerrostuneisuus.

Väestön demografinen rakenne riippuu paljon kaupungin tehtävästä. Itsenäiseen yhdyskuntaan sijoittuu toisenlainen väestö kuin nukkumakaupunkiin. Niillä on myös omat sosiaaliset ongelmansa. Tässä yhteydessä tuleekin kysyneeksi, mitkä ovat eri tehtäviä suorittavien yhdyskuntien sosiaaliset ongelmat, jotka johtuvat väestön sosiaalisesta rakenteesta? Tämä on erittäin laaja kysymys ja siitä on mahdollista tehdä lukuisia tutkimuksia. Mainittakoon vain eri suurten, eri ikäisten, eri nopeudella kasvaneiden ja eri tavoin rakennettujen yhdyskuntien sosiaalista rakennetta valaisevat tutkimukset. Näistä tutkimuksista suunnittelija saisi kuvan siitä, millaiseksi kokoonpanoltaan yhdyskunta muodostuu, miten pian se muuttuu ja mitä vaatimuksia tämä aiheuttaa suunnittelulle.
Sosiaaliseen ympäristöön kuuluu myös sosiaalisten suhteiden verkosto. Aivan samoin kuin suunnittelu vaikuttaa liikenneverkon muodostumiseen, se myös pääpiirteissään luo fyysillisen perustan sosiaalisten suhteiden verkostolle. Tutkimalla sosiaalisten suhteiden verkostoa erilaisissa olosuhteissa (seka-aineksinen - segregoitu; vanha - uusi asuntoalue; kerrostalot - rivitalot - omakotitalot; perheiden yksinäisten asuma-alueet jne.), saadaan viitteitä suunnittelulle.

Biologinen perusta. Biologinen ympäristö on vasta puutarhakaupunkiajatuksen mukana ruvennut askarruttamaan suunnittelijoita. Arvellaan näet, että puutarhakaupunki parhaiten tarjoaa biologisesti oikean urbaanisen ympäristön ihmiselle. Ilmeisesti näin onkin, ainakin mitä tulee luonnonläheisyyteen. Olisi kuitenkin tarkemmin tutkittava, onko ihmisillä ja millaisilla ihmisillä todella halu olla tekemisissä luonnon kanssa. Voisi olettaa, että puutarhakaupunki on sopivin urbaaninen miljöö niille, jotka ovat viettäneet maalla osan elämästään. Se saattaa olla sopiva myös perheentymisvaiheessa oleville, sillä puutarhakaupungit suunnitellaan familististen arvojen varaan.

\section{Kirjallisuus}

Allardt, Erik - Littunen, Yrjö. Sosiologia. Porvoo 1961.

Heinilä, Kalevi. Yhteiskunnan kaupungistuminen. Väestöntutkimuksen Vuosikirja VII, Vammala 1962.

Kiiskinen, Auvo. Eräitä empiiris-matemaattisia väestölakeja ja niiden sovellutuksia. Kansantaloudellinen Aikakauskirja 1954, 2. 